\title{
The Constrains Affecting Competitiveness of Emerging Household Citrus Farmers in Mpumalanga Province, South Africa
}

\author{
Teboho D. Manenzhe
}

\section{ABSTRACT}

\begin{abstract}
This study looked at the constrains affecting competitiveness on emerging citrus household farmers using primary data collected from a convenience sample of 150 emerging farming households in Nelspruit and Onderberg citrus administration regions of Ehlanzeni District Municipality of South Africa. The results showed that tertiary education and farming models influenced farming households to produce good quality citrus fruit and access both export and local fruit markets. In addition, study results indicated that other household socioeconomic constraints such as gender, age, training, business plan, water, input costs, barriers to engaging in farming on a commercial level, food safety, and good agricultural practice standards, and lack of title deed had a negative influence on the competitiveness of emerging household farmers in the study area. Policies that encourage a regular visit to farmers to follow up on the compliance of food safety and good agricultural practice standards by CGA advisors and agricultural extensionists are recommended for increased compliance.
\end{abstract}

Keywords: Citrus, competitiveness, emerging farmers, export markets, local markets.

\section{INTRODUCTION}

The purpose of this article is to assess constraints affecting competitiveness on emerging citrus household farmers with respect to (i) ability to produce good quality citrus, (ii) inability to access export, and (iii) informal fresh fruit markets. Poor fruit quality and lack of access to markets obstruct South African citrus industry to play a significant role in achieving the 2030 vision of the National Development Plan (NDP), which aims to grow the local gross domestic product at an annual rate of $5.4 \%$ and to add a further million jobs in the agricultural and agro-processing sector [1].

The South African Fruit industry is worth more than R77.9 billion of which citrus contributed R 19 billion of the gross value of the fruit industry, making South Africa the $12^{\text {th }}$ largest citrus producer in the world [2]. But these exist in a sea of partial or failure of robust participation of emerging citrus household farmers even though the government has reiterated equal participation in South African economy over the past two decades [3]. [4] show that progress with the transformation of the industry is slow. Black farmers grow citrus on small scale and export small quantities of citrus as compared to their White counterparts. Attempts to support Black farmers have resulted in very few farmers farming competitively [5]. As a result, Black citrus farmers are not competitive when measured based on the above conditions. In-competitiveness continues as reported for instances in several studies such as the profiling of the South African
Submitted : July 22, 2021

Published : September 06, 2021

ISSN: $2684-1827$

DOI: $10.24018 /$ ejfood.2021.3.5.343

\section{T. D. Manenzhe*}

Land Reform Advisor, Department of Agriculture, Land Reform and Rural Development, Nelspruit, South Africa. (email: tebogo.manenzhe@ gmail.com)

*Corresponding Author citrus market value chain, poverty alleviation and management model [6], [7], [2].

In-competitiveness has been credited to the following factors:

(i) Lack of title deeds that could be used as a form of collateral.

(ii) Lack of capacity and capability of Black citrus farmers to engage on commercial ventures.

(iii) Accessibility to support programs from the government and other role-players.

(iv) Incosistence of credit policies of various financial institutions.

(v) The rising costs of production.

(vi) Food safety and good agricultural practice standards. Assessing how these constraints affect emerging household citrus farmers is needed in order to recommend solutions that will lead to the competitiveness of this farming sector. According to [8], the literature on determinants of emerging household citrus farmer's competitiveness remains thin in South Africa while a substantial amount of effort has been directed to understanding determinants of the citrus sector's (in general) competitiveness, there is limited attention to why the majority of emerging household farmers are not competitive [2]. The majority of studies analyzed the competitiveness of the South African citrus industry in the face of the changing global health and environmental standards together with competitiveness trends [9] and [10], while other studies only analyzed the perceptions of emerging farmers on determinants of competitiveness [11].

To the best of my knowledge, no evidence is available in the country on the specific constraints affecting 
competitiveness on emerging household farmers. competitiveness behavior, particularly in Mpumalanga Province in [9]. Analyzing constraints of competitiveness in the emerging household citrus farmers is critical in designing carefully targeted policy interventions. This study, therefore, seeks to address this information gap. The study hypothesized that emerging household citrus farmers produce poor quality citrus and access only the local fresh fruit market than export fresh fruit market that far outweighed the local market in terms of revenue and profits. In the next section, the overview of South African citrus industry will be examined. This is followed by a research methodology and materials the study has employed. The study's results and discussion will then follow after research methodology. Finally, the study will provide a conclusion in the last section.

\section{OVERVIEW OF SOUTH AFRICAN CITRUS INDUSTRY}

The South African citrus fruit producers are facing rising costs of production and transport. With the rising costs, many farmers find it difficult to be competitive due to the additional burden on their budgets. The legislative requirements such as labour, water, and environmental laws and skills development requirements are also becoming cumbersome and making the business of citrus farming less competitive and unattractive. The poor performance by emerging farmers, lack of title deeds amongst these farmers, the inability of emerging farmers to engage in commercial ventures, and inaccessibility to support programs and funding from government and other role-players are also suggested to play a huge role on emerging farmer's in-competitiveness [2].

The citrus industry is an important foreign exchange earner. Citrus is one of the high-value products in Southern Africa that is mainly destined for the export market. It comprises five broad categories; namely oranges, easy peelers (soft citrus), grapefruit, lemons, and limes. The South African citrus industry is export-driven, thus making competitiveness a vital component of the production and marketing chain. There are currently 1400 producers of export citrus within Citrus Growers Association (CGA) membership in Southern Africa, including Zimbabwe and Swaziland. Of those producers, there are 141 emerging black farmers [8], [12], [3].

In South Africa, the industry contributes approximately R19.3 billion and an estimated number of over a million households depends on the citrus industry [4], [2]. The sector directly employs more than 100000 workers and contributes approximately $25 \%$ of total agricultural exports value [13] and emerging black farmers contribute about $2.1 \%$ to the national citrus export value. An unspecified number of people are also employed throughout the entire supply chain services, such as transport, port handling, and related services [4]. About $70 \%$ of South Africa's citrus is exported, with $19 \%$ of production being processed and the balance of $17 \%$ being sold on the local fresh markets [14]. Hence, the competitiveness of citrus fruit allows farmers to market their products to export markets where the returns are higher than the local markets. The competitiveness of this sector is a significant contributor to South African economic growth and the sector can continue to be an important source of employment.
Nevertheless, it is reported that the majority of emerging farmers supply the local market and higher returns from export markets are lost [15]. Citrus exports have declined in the Spain, Russian Federation, Oman, and Kuwait, and France markets [16]. In Africa, South Africa included, common local markets of citrus fruits include supermarkets, greengrocers, and hawkers. Supermarkets represent about $20 \%$ of the fresh fruit market, greengrocers $15 \%$ with hawker trade making up the balance [17]. However, recent requirements in food safety and good agricultural practices have compelled farmers to be competitive and engage in commercial ventures so that they can access export markets [2], [3]. Although, while a number of studies have focused on analyzing the competitiveness of the South African citrus industry [12]-[15] and [9], little attention has been paid to the specific elements causing some emerging citrus farmers to be competitive and access lucrative export markets.

The competitiveness of emerging citrus farmers has been considered an important element in boosting foreign exchange earnings and creates jobs in the citrus industry. They also improve food security; improve income and skills development [6], [18].

\section{Methodology AND MAterials}

\section{A. Study Area}

The study was conducted in Ehlanzeni District of Mpumalanga Province. Ehlanzeni is one of the major citrusgrowing areas in South Africa. Agriculture is the main occupation of people living in this area and citrus production relies heavily on irrigation. The province has a surface of $76495 \mathrm{~km}^{2}$ and is the second smallest province after Gauteng yet has the fourth-largest economy in South Africa.

The province is a summer rainfall area divided by the escarpment into Highveld region with cold frosty winters, and the Lowveld region with mild winters and a subtropical climate. An abundance of citrus fruit and many other subtropical fruits are produced in Mpumalanga [19]. According to the census results of 2011, Mpumalanga Province has a total population of 4039939 [20].

\section{B. Data Sampling, Collection and Analysis}

A multi-stage sampling procedure was followed for the selection of citrus growing emerging households farmers. This was done in consultation with the agricultural extension officers of the Department of Agriculture, Land Administration and Rural Development (DALARD) and land reform project officers of the Department of Agriculture, Land Reform and Rural Development (DALRRD). First stage: purposive selection of two citrus administrative regions in Ehlanzeni District. High citrus yields characterised these regions to ensure that there were adequate competitiveness activities. Eligible farmers included those farmers that produced citrus from the previous season and reported poor quality of the produce and lack of access to markets in the previous marketing season.

Using the selection criteria, the lists of the eligible population of farmers for each targeted region was obtained from DALARD and DALRRD respectively and a full list was developed accordingly. The non-random convenience sampling method was used to sample all 150 households for 
the study. Households chosen for the survey were citrus farmers, with the capacity to produce surplus citrus for export and for local sale.

Primary data was collected using a structured household questionnaire in face-to-face interviews. Data collected included farmers' demographics; land ownership, experience in citrus farming; business planning; access and use of infrastructure; quality and demand of the produce; access to markets; potential to access new markets; commercial barriers; meeting of export markets requirements and training.

The collected data was captured and manipulated using Statistical Package for Social Sciences (SPSS). In addition, a cross-tabulation model was used to quantitatively analyse the insights between categorical variables, understand the correlation between different variables and analyse the elements that cause competitiveness behaviour of household's citrus farmers. The idea behind the crosstabulation model is that it reduces the confusion that researcher might have encountered in dealing with data set and would help the present study to arrive at key findings.

\section{Analytical Model Used in the Study}

The revealed comparative advantage (RCA) model and relative trade advantage (RTA) method [21] informed the study of the household's decision on whether they are competitive and produce good quality commodity, access export/international and local markets. According to RCA, farmers will be competitive if they produce good quality commodities, access export/international and local markets. Farmers' competitiveness according to RTA, is mainly the ability to offset conditions such as uneven economic 'playing fields', distorted economies and different trade regimes.

As expounded by [22], household competitiveness is influenced by the ability of a farm to compete by trading its products at the time, place, and form within the global environment while earning at least the opportunity cost of returns on resources employed. In this study, it is assumed that emergent household farmers are not competitive because they produce poor fruits, cannot access both international and local markets.

\section{1) Dependent variable}

Competitiveness: The competitiveness outcome is categorized into three distinct groups: good quality of fruit, informal/local markets, and export/international markets respectively.

\section{2) Independent variables}

The study considered type of constrains and forms of improvement measures adopted by farmers to improve competitiveness behaviour. These include age, gender education, commercial barriers, input cost, experience, water, and global safety standards. Low levels of education and older farmers are the commonest constraints in South Africa, and hence were used as the reference category. Farmers' education was expected to positively influence farmers' competitiveness while age was considered to either improve the performance/quality of fruit. Farmers who are educated and in prime ages were more likely to produce a high-quality fruit and access export markets than informal local markets. Good quality fruit is less at risk of being turned down in the export markets than poor quality fruit, which will be sold to informal local markets.

The study also hypothesized that emerging household citrus farmers produce poor quality citrus and access only the local fresh fruit market than export fresh fruit market that far outweighed the local market in terms of revenue and profits.

Farming constraints were hypothesized to be the major issues hampering competitiveness in the study area. Access to new markets was expected to positively influence the competitiveness of farmers. Access to export markets helps farmers to comply with food safety, good agricultural practice as well as traceability and becomes competitive [2]-[10].

South Africa has a rich and diverse agricultural sector. It has a spectacular range of smallholder farming models. The country can be divided into distinct emerging farmers' models, and these models range from communal land reform farmers (CPA's), state/government farmers, and household farmers. The different farming models show a diversity of agricultural production systems and resource endowments of the emerging farmers [23] as determined by factors such as tenure systems, farm sizes, crop production systems, levels of technology use, management, and income levels. Emerging households' farmers are the least poor in terms of resources.

All the farming models represent the major citrusproducing households and it was expected that households from these regions would be more likely to be producing poor fruits and more likely to be accessing local fruit markets and more likely to be local fruit markets orientated than export fruit markets.

\section{RESUlTS}

\section{A. Households Characteristics and Farmers \\ Competitiveness}

The results of farmers' demographics and competitiveness by farming sector are presented in Tables I and II and those of farmers constraints are in Table III. Tables I show that the majority ( $80 \%$ ) combined of household's farmers were within the age category 36 -older than 65 years old while a minority (20\%) were youth. About gender, $50 \%$ were male compared to female $(50 \%)$. In terms of education, secondary school was the predominant $(70 \%)$ highest education by emerging household's model compared to primary $(20 \%)$ and tertiary (10\%). Farmers' age, gender, and education differed statistically significantly across farming models. High level of education such as tertiary that help improves fruit performance in the case of modern technology adoption, was commonly dominant in the state model, while middle-aged farmers (46-55) were prevalent in the state farming model. Male was visibly dominant in the state farming model.

The results in Table II indicate the age, gender, education, province, communal, and state. About $20 \%$ of the farmers were youth whilst the majority $(80 \%)$ were in the age category 46 to older than 65 years old. Although youth participation was not significant, most farmers were only able to access local fruit markets. Local fruit markets don't offer high returns and thus citrus farmers who rely on such markets may risk losing much of their revenue, as a result, not able to continue farming. While most farmers had secondary education $(70 \%)$, only a few had tertiary education $(10 \%)$. 
Accessing export fruit market was typically amongst farmers with tertiary $(100 \%)$ and $(50 \%)$ secondary education respectively. Access to the export market can increase farmer revenue and thus the sustainability of a farm.

Considering the location, the region represented $100 \%$ of the sampled farmers in the study with access to local fruit markets being the most, followed by the export market and lastly, good fruit quality. In terms of the farming model, communal land reform (CPA) farmers constituted the highest number of farmers in the study area, with 134 farmers, while state constituted 6 total number of the sampled farmers.

Furthermore, most of the farmers who had good quality fruit came from the communal $(51.5 \%)$ farming model, while most of the fruit exporters $(76.1 \%)$ and those selling the majority of fruit to informal markets $(66,4 \%)$ were found in the communal farming sector.

TABLE I: FARMER's DEMOGRAPHICS BY FARMING MODEL

\begin{tabular}{cccc}
\hline Variables & \multicolumn{3}{c}{ Farming sector $(\%)$} \\
\cline { 2 - 4 } & Sarimple & $\begin{array}{c}\text { Communal land } \\
\text { reform }\end{array}$ & State \\
\hline Age & 10 & 0,7 & 0 \\
$18-25$ & 10 & 1,5 & 0 \\
$26-35$ & 20 & 8,2 & 0 \\
$36-45$ & 20 & 35,1 & 66,7 \\
$46-55$ & 20 & 35,8 & 33,3 \\
$56-65$ & 20 & 18,7 & 0 \\
Older than 65 & & & 100 \\
Gender & 50 & 70,9 & 0 \\
Male & 50 & 20,1 & \\
Female & & & 0 \\
Education & 0 & 0,7 & 0 \\
No schooling & 20 & 15,7 & 83,3 \\
Primary & 70 & 53 &
\end{tabular}

TABLE II: HOUSEHOLDS CHARACTERISTICS BY FARMERS COMPETITIVENESS

\begin{tabular}{|c|c|c|c|c|}
\hline \multirow[b]{3}{*}{ Constrains } & \multicolumn{4}{|c|}{ COMPETITIVENESS } \\
\hline & \multicolumn{4}{|c|}{ Farmers' competitiveness (\%) } \\
\hline & Saniple & $\begin{array}{c}\text { Fruit } \\
\text { quality }\end{array}$ & $\begin{array}{l}\text { Export } \\
\text { market }\end{array}$ & $\begin{array}{l}\text { Local } \\
\text { market }\end{array}$ \\
\hline \multicolumn{5}{|l|}{ Age } \\
\hline $18-25$ & 10 & 0 & 0 & 100 \\
\hline $26-35$ & 10 & 0 & 0 & 0 \\
\hline $36-45$ & 20 & 0 & 0 & 10 \\
\hline $46-55$ & 20 & 25 & 50 & 75 \\
\hline $56-65$ & 20 & 0 & 0 & 0 \\
\hline Older than 65 & 20 & 0 & 0 & 50 \\
\hline \multicolumn{5}{|l|}{ Gender } \\
\hline Male & 50 & 0 & 0 & 30 \\
\hline Female & 50 & 20 & 40 & 80 \\
\hline \multicolumn{5}{|l|}{ Education } \\
\hline No schooling & 0 & 0 & 0 & 0 \\
\hline Primary & 20 & 0 & 0 & 50 \\
\hline Secondary & 70 & 0 & 50 & 100 \\
\hline Tertiary & 10 & 100 & 100 & 100 \\
\hline Province & 100 & 52,8 & 65,7 & 70,3 \\
\hline $\begin{array}{l}\text { Communal land } \\
\text { reform }\end{array}$ & 134 & 51,5 & 76,1 & 66,4 \\
\hline State & 6 & 50 & 66,7 & 50 \\
\hline
\end{tabular}

Source: own study.

Table III shows the results of farmers' competitiveness constraints. Out of the sampled farmers, the majority who received training were stated $(100 \%)$ while communal were the minority $(78.4 \%)$. The majority $(73.1 \%)$ of communal farmers and a minority of the household farming model $(30 \%)$ had business plans. However, significant differences in land ownership were observed between the households and state. The majority of the state $(66.7 \%)$ owned land in Title Deed, while very few (10\%) of households owned land in Title Deed.

The input costs were the highest constrain among all farming models followed by availability of irrigation water more particularly in households $(100 \%)$ and communal $(98.5 \%)$. The experience was a constrain in the majority $(82.8 \%)$ of communal and household model $(66.7 \%)$. In terms of commercial barriers, households $(100 \%)$ and $94 \%$ of communal were experiencing commercial barriers, indicating farmers' incompetence towards competitiveness. Inability to comply with food safety standards requirements was high in households $(100 \%)$ and $(83.6 \%)$ in communal models.

TABLE III: CONSTRAINS BY FARMING SECTOR

\begin{tabular}{cccc} 
TABLE III: CONSTRAINS BY FARMING SECTOR \\
\cline { 2 - 4 } Constrains & \multicolumn{3}{c}{ Farming sector $(\%)$} \\
\cline { 2 - 4 } & Sample & $\begin{array}{c}\text { Communal } \\
\text { land reform }\end{array}$ & State \\
\hline Training & 80 & 78,4 & 100 \\
Input cost & 100 & 100 & 100 \\
Experience & 60 & 82,8 & 33,3 \\
Business plan & 30 & 73,1 & 50 \\
Irrigation water & 100 & 98,5 & 83,3 \\
Commercial barriers & 100 & 94,0 & 66,7 \\
Food safety standards & 100 & 83,6 & 50 \\
Title Deed Land Ownership & 10 & 51,5 & 66,7 \\
\hline Source: own study. & \multicolumn{3}{c}{}
\end{tabular}

\section{DISCUSSION}

Tertiary education influenced farming households to produce good quality citrus fruit and access both export and local fruit markets. A high level of education helped farmers to adopt modern technology to manipulate citrus trees to produce high-quality fruits. This is in line with the findings of [6], who stated in a study of the impact of the Mabunda citrus project on poverty alleviation in the community of Xitlakati in the Greater Giyani Municipality of Mopani District in Limpopo Province in South Africa, that tertiary qualification provided capacity development and skills support system in citrus farming.

Furthermore, gender promoted the competitiveness behaviour, for example, females produced good quality fruit that accessed the local fruits market in high quantities. Although the result was not expected, the finding corresponds with the findings of [24], where women have the least access to the means for increasing output and yields, and for moving from subsistence farming to higher-value, but they produced more yields and good quality products than men. This result could also imply that competitiveness behaviour in households farming model in Mpumalanga Province could rise sharply if women had equal access to land and inputs. [25] noted that farmers who have access to land and support had better chances of farming competitively and export the produce. However, in contrast to this, [8] found that gender had a significant but not immense influence on market access of citrus farmers in South Africa. Therefore, gender is an important determinant of smallholder competitiveness [26]. Hence, policies that promote emerging household farmers' competitiveness should include both men's and women's 
need for the equitable contribution of farmers in export markets as these markets provide farmers with an opportunity to sustain their farms and create employment through citrus sales. The influence of age on competitiveness suggests that farmers aged 18-35 were more likely to produce poor fruits and access local fruit markets than export markets. This is expected as young farmers are likely to lack resources and experience than middle-aged and old farmers due to their lack of involvement in farming at an early age [27]. This result corresponds with the findings of [8] who found that a typical South African smallholder citrus producer is 45 years old. Policies that promote youth participation in citrus farming are highly recommended.

Training had a positive influence on competitiveness. Training promoted access to local fruit markets of emerging household farmers in this area. This could be explained by the fact that training provides skills to improve productivity, increase adaptability to deal with change and crisis, and manage risks. Other studies [3], [28] attested to this. Untrained farmers are less empowered to manage their businesses effectively and profitably in a competitive and often hostile environment. This result is in line with other studies on management ability which established that training is inversely related to the competitiveness of the farmers [29], [30]. Policies that promote farmer training at the household farming model are thus key to ensure the competitiveness of smallholder households in the citrus industry.

The positive influence of business plan on competitiveness behaviour suggests that emerging household farmers were more likely not to be competitive. This is expected as the business plan is likely to guide how the farmer will achieve the farm's goals and sustain a competitive advantage over their counterparts [31], [32]. This result corresponds with the findings of [7] who found a positive and significant effect of business plan on competitiveness behaviour of citrus farmers in KwaZulu Natal Province in South Africa.

Citrus requires a constant supply of water to maintain optimal yields and fruit quality [13]. The lack of irrigation water affected the competitiveness of emerging household farmers in the area. This could be explained by the fact that South Africa stands out as one of the most water-scarce countries within Southern Africa [33]. [34] attested to this. However, in contrast to this, [15] found that the availability of water for the South African citrus industry is favorable. Therefore, policies that promote the saving of water are needed to ensure that farmers' irrigation infrastructure is well designed to deliver water according to the orchard's requirements and be well maintained with no blockages and leakages.

Input costs had a negative influence and constraint to the emerging household's competitive success. The high input costs of farming downgraded fruit quality of emerging household farmers in the area. This could be inferred to the fact that farmers find it costlier to afford high prices of input costs, resulting from a weakening currency and increasing administrative costs, higher charges for electricity and labour. [10] attested to this. Farming sectors with low costs of doing business are considered to be business-friendly and are likely to attract investors and to have farmers that have a better chance of being and becoming profitable and competitive. This result corresponds with a study on determinants of competitiveness in the South African citrus fruit industry which recognized that the high cost of doing business is inversely related to constraints hampering farmers' competitiveness [15], [30]. This indicates that a large part of emerging household farmers is gravely concerned about this phenomenon. Thus, current capacity development, infrastructure development and operational inputs policy such as Recapitalization and Development Program (RADP) should be reviewed to ensure that the department release the input funds faster and as per the specific business plan's disbursement procedures.

The ability to engage in commercial farming was negative. This implies that commercial farmers were more likely to be competitive compared to subsistence farmers. Commercial farmers are more concerned about gaining, retaining, and optimizing markets than their counterparts. More so, awareness of all the barriers that they may encounter when trying to get their produce onto foreign and domestic shelves is relevant for farmer competitiveness advantage henceforth, the positive influence on farmer competitiveness. [2] found a similar result in a profile of the South African citrus market value chain. Policies that promote the household production of citrus should support emerging household farmers to engage in farming on a commercial level to increase their production levels, quality and thus participate in the market as exporters of citrus.

Food safety and good agricultural practice standards had a negative influence on competitiveness. Failure to follow food safety and good agricultural practice standards hindered the competitiveness of emergent household farmers in the area. It could be inferred that farmers find it more difficult to adhere to food safety and good agricultural practice standards due to the cost of compliance with the standards, running costs of traceability systems, cost of facility maintenance, and food safety measures. This result is in line with [9] who found a similar result in a study on the competitiveness of the South African citrus industry in the face of the changing global health and environmental standards. CGA and agricultural extension officers assigned to assist emerging household farmers should regularly visit farmers to follow up on the complaint of food safety and good agricultural practice standards.

Another constraint that negatively impacted emerging household citrus farmers' competitiveness was the lack of Title Deed for their farms. It can allude that farmers could have used their Title Deed as collateral for financial resourcing to cover input costs and infrastructure development costs. [3] stated similar findings in the Annual Report 2017/2018. However, in contrast to this, [35] found that the use of Title Deeds as collateral had less impact on farmers' ability to access finance in South Africa. Therefore, the Title Deed is an important determinant of emerging household farmers' competitiveness [16]. Hence policies that allow emerging smallholder citrus farmers to own land in Title Deed are encouraged to improve the environment under which emerging household farmers are operating.

\section{CONCLUSION}

Overall, farmers participate in citrus farming to sell their products into two arenas, being the local fresh fruit market 
and the export fresh fruit market. This contributes to poverty reduction through income realized from sales, improved food security, and reduce unemployment as farmers employ communities' members. While a substantial amount of effort has been directed at understanding the competitiveness of South African Citrus Industry in the face of the changing global health and environmental standards, there is still limited information as to what constraints affect the competitiveness of emerging household citrus farmers in South Africa.

Competitiveness is a critical component of farm management among citrus farmers in South Africa and has the potential to contribute to farm incomes and food security. Hence, this study looked at the constraints affecting competitiveness behaviour on emerging household farmers. Using primary data collected from a convenience sample of 150 emerging citrus farming households in Nelspruit and Onderberg citrus administration regions of Ehlanzeni District Municipality of South Africa. The results showed the importance of various constraints affecting farmers' competitiveness. Tertiary education and farming models influenced farming households to produce good quality citrus fruit and access both export and local fruit markets, suggesting that higher education and type of education are critical to enhancing the competitiveness of emerging household farmers. Thus, policies that encourage investment in higher education training are highly recommended. Government should also design policies and develop programs to increase farmers' awareness of tertiary education and benefits of education of farmer's competitiveness.

In addition, study results indicated that other household socioeconomic constraints such as gender, age, training, business plan, water, input costs, barriers to engaging in farming on the commercial level, food safety, and good agricultural practice standards, and lack of Title Deed had a negative influence on the competitiveness of emerging household farmers in South Africa. Overall, policies that encourage a regular visit to farmers to follow up on the complaint of food safety and good agricultural practice standards by CGA and agricultural extension officers are recommended for increased compliance.

\section{ACKNOWLEDGMENT}

The author would like to thank all participants in this research who contributed to achieve the intended objectives and purposes.

\section{REFERENCES}

[1] NPC (National Planning Commission), 2011. National Development Plan. Pretoria, Government Printers, Pretoria, South Africa.

[2] DAFF (Department of Agriculture, Forestry and Fisheries), 2019. A profile of South African citrus market value chain. Pretoria.

[3] CGA-GDC (Citrus Growers Association - Growers Development Company), 2018. Annual Report 2017/2018, CGA-GDC.

[4] Genesis AJ, 2018. Oranges and labourers: The potential for job creation in the citrus sub-sector of South Africa, Working Paper No 54. PLAAS, University of Western Cape, South Africa.

[5] Mabuza NN \& Machete C, 2016. Socio-economic of land reform benefiting from the Recapitalization and Development Programme in South Africa, master's dissertation, University of Pretoria, South Africa.
[6] Mashila DM \& Moyo T, 2011. The impact of Mabunda Citrus Project on poverty alleviation in the community of Xitlakati in the Greater Giyani Municipality of Mopani District in Limpopo Province, master's dissertation, University of Limpopo, South Africa.

[7] Terblanche SE, Stevens JB \& Sekgota MG, 2014. A comparative analysis of two models: The Mashishimale farm management model and the Nkumbleni strategic partnership model, South Africa, Journal of South African Agricultural Extension, 42 (2) 81- 102.

[8] NAMC (National Agricultural Marketing Council), 2019. The Smallholder Market Access Tracker (SMAT). Baseline report: A case of smallholder citrus producers in South Africa.

[9] Ndou P \& Obi A, 2012. The competitiveness of the South African citrus industry in the face of the changing global health and environmental standards, doctoral thesis, Department of Agricultural Economics and Extension Faculty of Science and Agriculture, University of Fort Hare, South Africa.

[10] Dlikilili X \& van Rooyen J, 2018. Measuring the competitive trends of the South African citrus industry. SA-TIED | Working Paper 11 | May 2018

[11] Tshikolomo KA, Nesanvuni AE, Mpandeli NS \& Makhuvha L, 2017. Perceptions of smallholder farmers on determinants of competitiveness of the citrus industry in Vhembe District, Limpopo Province, South Africa. Journal of Human Ecology, 59 (201) 2-3.

[12] Dlikilili X, 2018. An analysis of the competitive performance of the South African citrus industry, masters dissertation, University of Stellenbosch, Cape Town.

[13] Vahrmeijer JT, Grout TG \& Taylor NT, 2015. Water research in citrus. Citrus Research International and University of Pretoria, South Africa

[14] CGA (Citrus Growers Association), 2018. Annual Report 2017/18, CGA.

[15] Sinngu T \& Antwi M, 2014. Determinants of Competitiveness in the South African Citrus Fruit Industry. Journal of Agricultural Science, 6 (12) 1916-9760.

[16] DAFF (Department of Agriculture, Forestry and Fisheries), 2017. A profile of South African citrus market value chain. Pretoria.

[17] DARDLA (Department of Agriculture, Rural Development and Land Administration), 2011. Business plan for Champagne Estate fruit and vegetables projects. Directorate: Agricultural Economics and Marketing, Nelspruit.

[18] Peter BD \& Sibanda O, 2017. The impact of Post-apartheid agricultural changes on citrus farmers in the Peddie Area, master's dissertation, Fort Hare University, South Africa.

[19] MPG (Mpumalanga Provincial Government), 2020. About Mpumalanga Province, the people, agriculture industry and manufacturing. Available http://www.mpumalanga.gov.za/about/province.htm (accessed 8 June 2020).

[20] StatsSA (Statistics South Africa), 2011. Population Census 2011 Pretoria, South Africa.

[21] Van Rooyen CJ, Esterhuizen D \& Stroebel L, 2011. 'Analyzing the Competitive Performance of the South African Wine Industry'. International Food and Agribusiness Management Review, 14(4) 179200.

[22] Freebairn J, 1986. 'Implications of Wages and Industrial Policies on Competitiveness of Agricultural Export Industries'. Paper read at the Australian Agricultural Economics Society Policy Forum, Canberra, Australia.

[23] Greenberg S, 2013. The disjuncture of land and agricultural reform in South Africa: Implications for the agri-food systems, Working Paper 26, PLAAS, University of Western Cape, South Africa.

[24] FAO (Food and Agricultural Organization), 2009. Bridging the gap, FAO'S programme for gender equality in agriculture and rural development, Rome, Italy.

[25] Business Trust \& Department of Provincial Local Government (DPLG), 2007. Nodal economic profiling project, Bushbuckridge, Nelspruit.

[26] Agholor AI, 2019. Gender gap in Sub-Saharan Africa, reminiscence of rural extension and advisory services: delineation, challenges and strategies. South African Journal of Agricultural Extension. 47 (3), 4660.

[27] CGA (Citrus Growers Association), 2020. Annual Report 2019/20, CGA.

[28] Terblanche SE, 2011. Mentorship a key success factor in sustainable land reform projects in South Africa, Journal of South African Agricultural Extension, 39: 55-74.

[29] Land Bank, 2011. Addressing challenges of financing emerging farmers. Agricultural Economic Research and Innovation Service (AERIS), Research report. Pretoria.

[30] DRDLR (Department of Rural Development and Land Reform), 2013. Three years review of recapitalization and development programme. 
Policy for the Recapitalization and Development of the Department of Rural Development and Land Reform. Pretoria.

[31] SBASA (Standard Bank Agribusiness SA), 2013. Finance and farm management. Thirteenth edition. Johannesburg, South Africa.

[32] Bekker MC \& Mashaba JT, 2018. A critical review of agricultural related construction project failures at the Department of Agricultural, Rural Development and Environmental Affairs (DARDLEA): Mpumalanga Province. South African Journal of Agricultural Extension. 47 (1) 83-91.

[33] Turton AR, 2000. Precipitation, People, Pipelines and Power in Southern Africa: Towards a 'Virtual Water'-based Political Ecology Discourse. In P. Stott and S. Sullivan (Eds.) Political Ecology: Science, Myth and Power. London: Arnold \& New York: Oxford University Press.

[34] Ncube BL, 2018. Institutional support systems for small-scale farmers at New Forest Irrigation Scheme in Mpumalanga, South Africa: Constraints and opportunities. South African Journal of Agricultural Extension, 45 (2), 1-13.

[35] Oladele OI \& Mokgadi FJ, Factors affecting sustainability of agricultural projects on poverty alleviation in Gauteng Province of South Africa, Journal of Food, Agriculture \& Environment, 11 (2), 1078-1086. 2013.

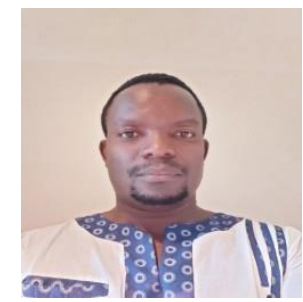

Dr Teboho D. Manenzhe (PhD, University of Free State (UFS), South Africa) is a Senior Land Reform Advisor in the Department of Agriculture, Land Reform and Rural Development. The primary research interests include agricultural extension, sustainable agriculture, smallholder development, agricultural economics, rural development, and agricultural management. 